\title{
DYNAMIC MECHANICAL AND WATER ABSORPTION PROPERTIES OF MICROCRYSTALLINE CELLULOSE REINFORCED POLYPROPYLENE COMPOSITES: THE EFFECT OF UNCONVENTIONAL IRRADIATION ROUTE
}

\author{
Noorasikin Samat* ${ }^{*}$ Nurul Hakimah Mohd LaZim, ZahUrin Halim \\ Department of Manufacturing and Materials, Faculty of Engineering, \\ International Islamic University Malaysia, \\ P.O. Box 10, 50728 Kuala Lumpur, Malaysia. \\ "Corresponding author: noorasikin@iium.edu.my
}

(Received: $25^{\text {th }}$ January 2019; Accepted: $5^{\text {th }}$ July 2019; Published on-line: $2^{\text {nd }}$ December 2019)

\begin{abstract}
The unconventional electron beam (EB) irradiation route in preparing microcrystalline cellulose (MCC) fiber reinforced recycled polypropylene (rPP) composites was studied. In this route, the rPP was first subjected to EB irradiation at various doses (10-50kGy) and was then used as a compatibilizer. Unirradiated and irradiated rPPs were blended at two different ratios $(90: 10 ; 50: 50)$ and added with MCC at contents of 5, 20 and 40wt\%. Dynamic mechanical analysis (DMA) and water absorption tests were carried out. The DMA spectra exhibited high stiffness and damping behaviour. As the content of MCC increased, the water resistance of composites dropped slightly as compared to the controlled rPP. However, some compositions (50:50/40MCC-10kGy and 50:50/5MCC-50kGy) had shown opposite results. The improvement in the studied properties proved the existence of the compatibility effect that occurred at low irradiation doses, and also depended on the ratio (unirradiated and irradiated $\mathrm{rPP}$ ) and MCC contents.
\end{abstract}

ABSTRAK: Kaedah sinaran gelombang elektron secara bukan konvensional dalam penyediaan komposit polipropilena kitar semula (rPP) bersama serat selulosa mikrohablur (MCC) telah dikaji. Dalam kaedah ini, rPP telah didedahkan kepada sinaran gelombang elektron dengan dos yang berbeza (10-50kGy) dan kemudiannya digunakan sebagai penserasi. rPP tidak tersinar dan tersinar telah dicampur dengan nisbah (90:10; 50:50) dan ditambah dengan MCC pada kandungan 5, 20 and 40wt\%. Analisis dinamik mekanikal (DMA) dan ujian penyerapan air telah dijalankan. Spektrum DMA menunjukkan sifat kekakuan dan pengenduran yang tinggi. Apabila kandungan MCC bertambah, kerintangan komposit terhadap air berkurang sedikit berbanding rPP terkawal. Bagaimanapun sebahagian komposisi (50:50/40MCC-10kGy and 50:50/5MCC-50kGy) telah menunjukkan keputusan sebaliknya. Penambahbaikan sifat bahan dalam kajian ini membuktikan kewujudan kesan keserasian yang berlaku pada dos sinaran rendah, dan juga bergantung kepada nisbah (rPP tidak tersinar dan tersinar) dan kandungan MCC.

KEYWORDS: polypropylene; cellulose; compatibilizer; electron beam irradiation; mechanical properties

\section{INTRODUCTION}

The changing of chemical, structural, and other physical properties of polymers through the application of ionizing radiation (IR) is not a new technique. Of all the 
existing irradiation methods, the most common modes of IR used are the gamma irradiation and electron beam (EB) processing. There are a few advantages to the use of EB irradiation. It is fast, simple, can be carried out at room temperature, and the technology is completely environmentally friendly. During the irradiation process, the energy is transferred from the irradiating source to the atoms of irradiated materials. This will result in a few chemical reactions taking place, such as chain scission, branching, and crosslinking [1-2] that subsequently alter the mechanical and thermal properties of the materials [2-7]. Generally, the formation of crosslinking will lead to improvements of properties. Many industries, such as those producing heat shrink tubes, crosslinked wires and cables, packing films, and foams have adopted the EB radiation technique in their product development segment [8-9]. EB processing is also used for sterilization of medical devices, drug delivery systems, preservation of food, and surface curing [10-11]. Due to its wide usage, numerous published works have employed EB techniques in the study of polymer composites.

In the conventional route for polymer composites, the IR is usually applied after the composites have been fabricated [12-14]. However, a new irradiation route for preparing reinforced polymer composites has been reported by Karsli et al. and Gomes et al., where the polypropylene (PP) that was exposed to gamma and EB irradiation respectively, was compounded with short carbon and piassava fibers [15-16]. Tensile tests were performed in both cases to evaluate the function of irradiated PPs as a compatibilizer. This unconventional irradiation route had also been further explored in our previous works [2$5]$ in recycled polypropylene (rPP) that was reinforced with microcrystalline cellulose (MCC). Here, the possibility of irradiated recycled PP being a compatibilizer was assessed based on the tensile, impact strength and thermal properties. In all of these cases [2-5, 15$16]$, the properties of composites had been better than the controlled polymer, thereby proving the compatibility effect of the virgin PP or recycled PP through the use of IR.

Apart from using coupling agents to improve the compatibility between natural fiber and polymer [17-19], the use of EB via the unconventional irradiation route would offer an alternative solution in overcoming this drawback. The major advantage of this route is that the modification was carried out on the polymer matrix itself without any chemical modifier or coupling agent. Therefore, the present work aims to further investigate the effects of irradiated recycled PP on dynamic mechanical analysis (DMA) and water absorption properties from the developed composites. The results derived from this analysis is a supplementary research on an earlier study conducted by Lazim et al. [2-3] and Samat et al. [4].

\section{MATERIALS AND METHOD}

\subsection{Materials}

Recycled polypropylene (rPP) from industrial waste was purchased from Top Flow Sdn. Bhd., Shah Alam, Selangor. The reinforcement material was microcrystalline cellulose (MCC) in the form of a fine white powder with a density of $0.6 \mathrm{~g} / \mathrm{cm}^{3}$, which was obtained from Sigma-Aldrich Co. (M) Sdn. Bhd. The polymer and the MCC had been dried in an oven at $40-60{ }^{\circ} \mathrm{C}$ for at least 7 hours before use.

\subsection{Preparation of Composites}

The rPP pellets were irradiated using a $3 \mathrm{MeV}$ electron beam (EB) using the EB model EPS-3000 at room temperature under oxygenated conditions. Irradiation doses were varied 
at 5, 10, and $50 \mathrm{kGy}$, respectively. The unirradiated and irradiated rPP pellets were blended at corresponding ratios of 90:10 $\mathrm{wt} \%$ and 50:50 $\mathrm{wt} \%$ according to weight before being added with the various MCC loadings $(5,20$, and $40 \mathrm{wt} \%)$ using a Brabender twin screw extruder machine at a screw speed of $70-90 \mathrm{rpm}$. The compounded materials were pelletized and fed into Battenfield HM 600/850 injection moulding to form specimens according to the testing standards (ASTM: D638).

\subsection{Dynamic Mechanical Analysis (DMA)}

Dynamic Mechanical Analysis was conducted over a wide range of temperatures as a means of studying the viscoelasticity behaviour of the materials. DMA was conducted using a Perkin Elmer Pyris Diamond DMTA machine using ASTM D7028. The testing was carried out in three-point bending mode at a frequency of $1 \mathrm{~Hz}$. The temperature range was $-50{ }^{\circ} \mathrm{C}$ to $150{ }^{\circ} \mathrm{C}$ with heating rate at $5{ }^{\circ} \mathrm{C} / \mathrm{min}$. The storage modulus (E') and damping factor $(\tan \delta)$ of the samples were measured as a function of temperature.

\subsection{Water Absorption}

All of the samples had been immersed in distilled water for seven days in a closed container at room temperature. The samples were wiped with tissue and weights were recorded for the initial two 6 hours, which was followed by the next 12 hours and subsequently 24 hours with the whole process repeated until day seven. The percentage of increase in water in relative to the initial weight of each sample was reported as the amount of water absorbed. Six samples of replicated specimens for each composition were used to obtain the average value. The water absorption percentage after being soaked $\left(M_{t}\right)$ was calculated according to Eq. (1) (ASTM D570-98):

$$
M_{t}(\%)=\frac{\left(w_{f}-W_{i}\right)}{W_{i}} x 100
$$

where $\mathrm{W}_{i}=$ initial and $\mathrm{W}_{f}=$ final weight, respectively.

\subsection{Gel Content Analysis}

The result of gel content for neat rPP and rPP/MCC composite samples has been reported in our previous work [2]. The gel content of was determined by the extraction of samples in xylene solvent at $130^{\circ} \mathrm{C}$ for $24 \mathrm{~h}$ (ASTM D2765). These samples were dried and weighed and the gel fraction was calculated as:

$$
\text { Gel fraction }(\%)=\frac{W}{W_{o}} \times 100
$$

where $\mathrm{W}_{0}=$ initial and $\mathrm{W}=$ final weight, respectively.

\section{RESULTS AND DISCUSSION}

\subsection{Dynamic Mechanical Analysis (DMA)}

Figure 1 shows the effect of rPP:i-rPP ratio, MCC content and the irradiation dosage to the storage modulus (E') of the $\mathrm{rPP}$ reinforced with $40 \mathrm{wt} \% \mathrm{MCC}$ fibers. It was observed that in the glassy region, the E' of the neat rPP and rPP:i-rPP/MCC composites had remained fairly constant before gradually decreasing across the measured temperature ranges. No rubbery plateau was noticed in these DMA curves. Upon further analysis, it was observed that there had been a greater increase of the E' of the rPP:i-rPP/MCC composites as compared to the neat rPP. This implies that the addition of MCC fibers had enhanced the stiffness by restricting the flow of rPP matrix, which is in line with the results obtained from Young's modulus [3-4]. The storage moduli at specific 
temperatures; $-50{ }^{\circ} \mathrm{C}$ (glassy region), $+27{ }^{\circ} \mathrm{C}$ (room temperature) and $+100{ }^{\circ} \mathrm{C}$ (possible use temperature) were selected as a means of comparing the effect of rPP:i-rPP ratio and irradiation dose. The results are presented in Table 1.

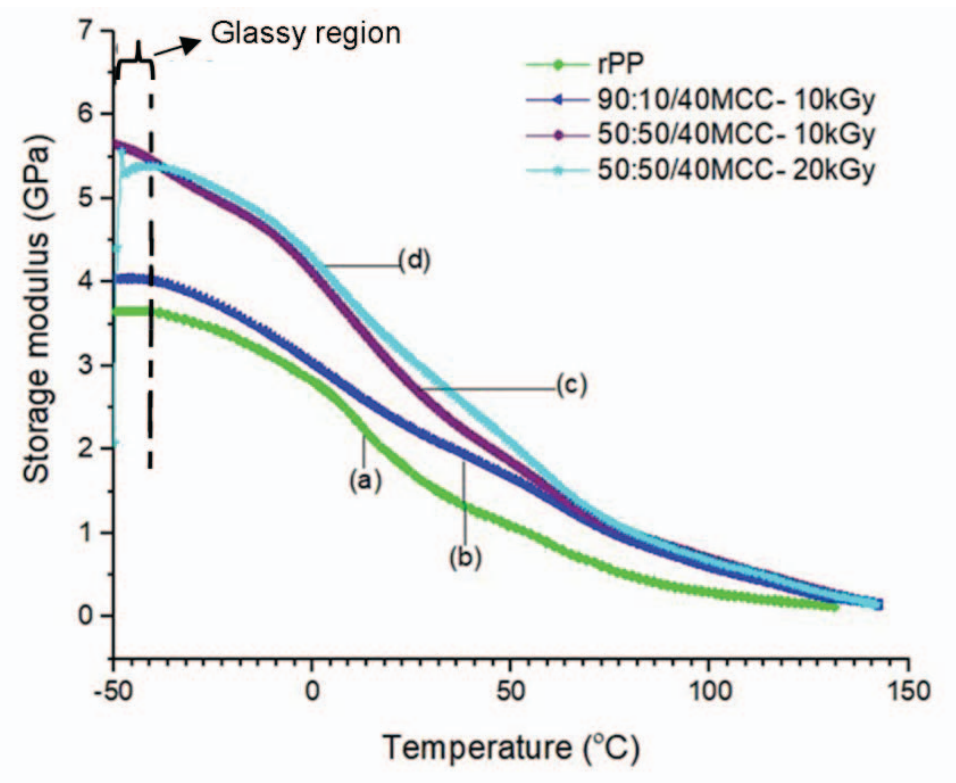

Fig. 1: The storage moduli of (a) neat rPP, (b) 90:10/40MCC-10kGy, (c) 50:50/40MCC-10kGy, and (d) 50:50/40MCC-20kGy.

Table 1: Storage moduli and $\mathrm{T}_{\mathrm{g}}$ values of $\mathrm{rPP}$ and $\mathrm{rPP}$ : i-rPP/MCC composites

\begin{tabular}{|c|c|c|c|}
\hline Samples & $\begin{array}{c}\mathrm{E}^{\prime} \text { at }-50^{\circ} \mathrm{C} \\
\text { (MPa) }\end{array}$ & $\begin{array}{c}\mathbf{E}^{\prime} \text { at }+27^{\circ} \mathrm{C} \\
\text { (MPa) }\end{array}$ & $\begin{array}{c}\mathrm{E}^{\prime} \text { at }+100^{\circ} \mathrm{C} \\
\text { (MPa) }\end{array}$ \\
\hline $\mathrm{rPP}$ & 3000 & 1620 & 294 \\
\hline 90:10/40MCC- $10 \mathrm{kGy}$ & 4033 & 2184 & 585 \\
\hline 50:50/40MCC-10kGy & 5662 & 2658 & 691 \\
\hline 50:50/40MCC-20kGy & 4310 & 2986 & 658 \\
\hline
\end{tabular}

At $-50{ }^{\circ} \mathrm{C}$, the increase of the storage moduli of composites with $10 \mathrm{kGy}$ i-rPP at 50:50 ratio was larger than that of 90:10. Moreover, the difference in the storage moduli values of sample 50:50 at $20 \mathrm{kGy}$ is an indication the benefit derived from i-rPP as a second contributor to the enhancement of stiffness. Previously, it was found that at a ratio of 50:50, the increase in the stiffness of composites was dominated by the presence of higher MCC content and that the presence of i-rPP promoted a 'compatibilizing effect' [4]. From the FTIR [2] and morphological analysis [2-4], this effect is attributed through the formation of crosslinking and better filler-matrix interfacial adhesion, respectively. The existence of crosslinking in the 50:50/40MCC-10kGy sample was evident in its FTIR spectra through the absence of the absorption peak assigned to a carbonyl group $(\mathrm{C}=\mathrm{O})$ [2]. According to Lazim et al., the disappearance of this absorption peak shows the suppression of the oxidation process associated with the presence of crosslinking structure [2]. In contrast, for the $90: 10 / 40 \mathrm{MCC}-10 \mathrm{kGy}$ sample, the absorption peak of the carbonyl group was pronounced. Therefore, it is likely, a higher i-rPP content had formed harder domains in the rPP through the formation of greater crosslinking, thereby increasing the 
E'. The influence of greater crosslinking to the increase of storage modulus of composites was also reported by Banik et al. and Pang et al. [20-21].

It is worth noting that the improvement in the storage modulus had occurred at a low irradiation dose (10 kGy). Earlier on, it was discovered that that higher dosage had led to chain scission; which also reduced the level of crosslinking [2]. From Table 1, when the temperature was increased from -50 to $+100{ }^{\circ} \mathrm{C}$, it was evident that there was a reduction in the values of E', indicating a shift to the rubbery phase. The changing of phase was due to the loosening of chains between the $\mathrm{PPP}$ and MCC fibers that led to the increased flexibility of the composite. It was noticed that the E' value of rPP had dropped considerably compared to those of the composite samples.

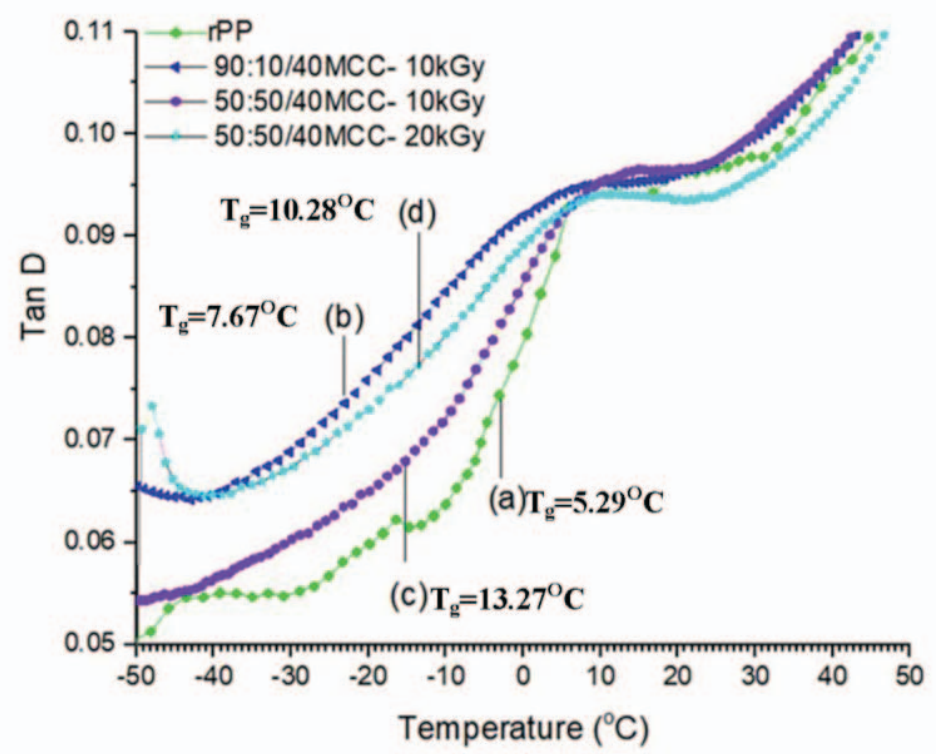

Fig. 2: The tan D of (a) neat rPP, (b) 90:10/40MCC-10kGy, (c) 50:50/40MCC-10kGy, and (d) 50:50/40MCC-20kGy.

Results of the damping behaviour of rPP composites along with their glass transition temperature $\left(\mathrm{T}_{\mathrm{g}}\right)$ values are presented in Figure 2. As seen from the illustration, the neat rPP has the lowest $\mathrm{T}_{\mathrm{g}}$ value, which is $5.29^{\circ} \mathrm{C}$. The deviation relative to $\mathrm{rPP}$ was evident for the composite samples, where the $\mathrm{T}_{\mathrm{g}}$ had shifted to higher values. This finding had also validated the existence of crosslinking in the rPP composites. According to Wongsuban et al., cross-linked structure inhibits the mobility of the polymer chains [22]. Consequently, a higher temperature is required to trigger the change of phases (glassy to rubbery) in the rPP matrix, which was demonstrated by the marked increment in the sample of rPP:i$\mathrm{rPP} / 40 \mathrm{MCC}-10 \mathrm{kGy}\left(\mathrm{T}_{\mathrm{g}}=13.27^{\circ} \mathrm{C}\right)$. In fact, this enhancement had almost doubled as compared to $\mathrm{rPP}\left(\mathrm{T}_{\mathrm{g}}=5.29{ }^{\circ} \mathrm{C}\right)$, suggesting that the sample had the most prominent compatibilizing effect. Interestingly, unlike the other natural fiber reinforced polymer system; the intensity of the tan delta peak had declined with the increase of filler content [19, 23-24]. Nevertheless, in our case, the peak curve of tan delta of sample rPP:irPP/40MCC-10kGy was observed to be higher than the rPP, which suggests a better damping behaviour. Indeed, the similar sample (50:50/40MCC-10kGy) had also demonstrated substantial improvement of the impact strength as reported in our earlier work [2]. 


\subsection{Water Absorption}

Figure 3 depicts the water absorption results for the neat rPP and composite samples. In general, the composites had exhibited a higher water uptake percentage as compared to the neat $\mathrm{rPP}$ at all immersion time and composition ranges. This was due to the addition of hydrophilic MCC fibers into the polymer matrices, which had increased the ability of rPP composites to absorb more water. During the initial immersion period $(<12 \mathrm{hr})$, the difference in the water absorption percentages for all samples had been negligible. As observed in Figure 3, the water uptake of composites had increased steadily after the immersion period was extended beyond 24 hours. This result was expected due to the increased interaction between the hydrogen molecule from water and the $-\mathrm{OH}$ molecule from the MCC fibers. Nevertheless, the overall water uptake of the composites is considered low since the highest percentage shown was less than $5 \%$. Therefore, it is suggested that i-rPP promotes the hydrophobicity of the rPP/MCC composites through the formation of better interfacial adhesion.

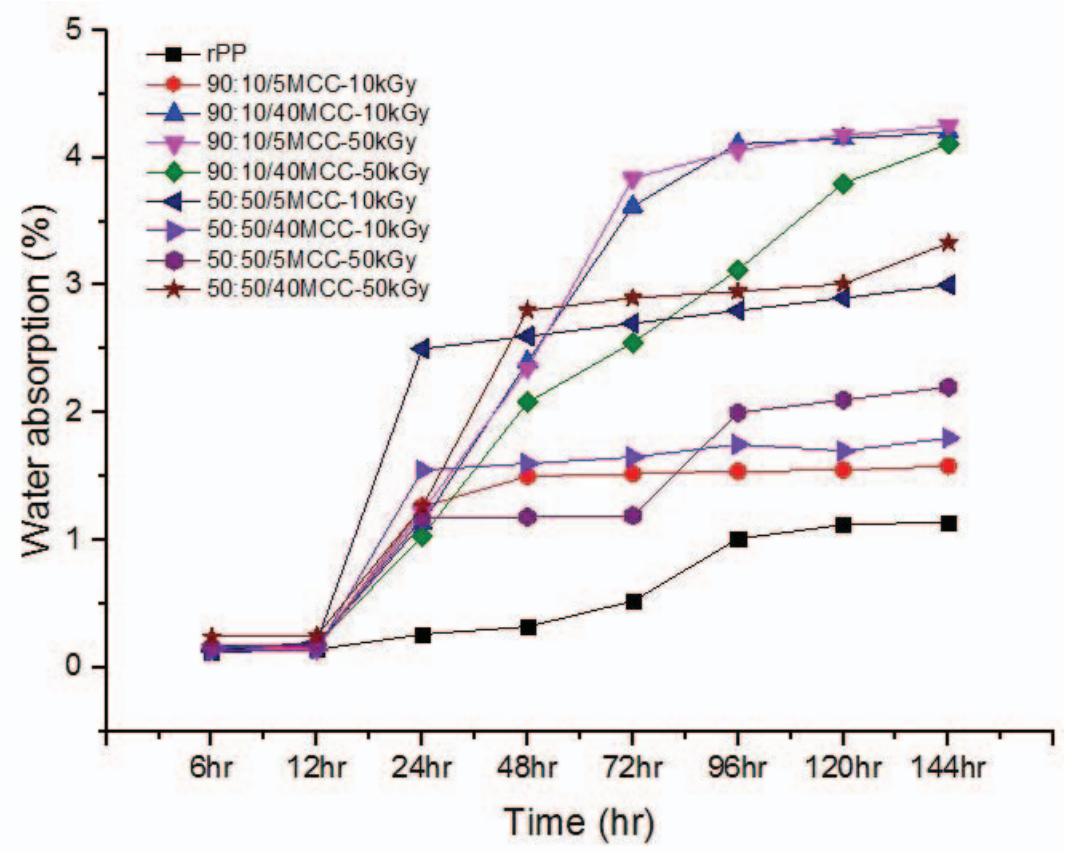

Fig. 3: Water absorption percentage of $\mathrm{rPP}$ and $\mathrm{rPP} / \mathrm{MCC}$ composites over a period of seven days.

As discussed earlier, the varied irradiation doses along with the MCC content caused different crosslinking densities, which subsequently affected the filler-matrix interfacial adhesion. To gain a better perspective on this circumstance, a comparison between the gel content (Table 2) and water uptake results (Fig. 3) was made. Apparently, the composites that possessed higher gel content value had shown a better water resistance than those with lower gel content values. Hence, it is suggested that higher crosslinking densities decrease the diffusion rate of water molecules in the composite, which subsequently leads to lower water uptake. A lower crosslinking density, on the other hand, would only ease the diffusion of water molecules mainly in the amorphous parts [25]. Furthermore, the decrease in the water absorption in this work is similar to the case in natural fiber/polymer composites treated with coupling agent [26-27]. This observation indicates that the introduction of i-rPP was beneficial to improve resistance against water absorption. 
Table 2: Water absorption and gel content percentage of rPP/MCC composites

\begin{tabular}{ccccccc}
\hline Ratio & Sample & $\mathbf{1 2 h r}$ & $\mathbf{2 4 h r}$ & $\mathbf{9 6 h r}$ & $\mathbf{1 4 4 h \mathbf { h }}$ & Gel content (\%) [2] \\
\hline \multirow{5}{*}{ 90:10 } & 5MCC-10kGy & 0.523 & 1.178 & 1.557 & 1.662 & - \\
& 40MCC-10kGy & 0.127 & 1.184 & 4.083 & 4.271 & 13.16 \\
& 5MCC-50kGy & 0.445 & 1.138 & 3.992 & 4.121 & - \\
& 40MCC-50kGy & 0.118 & 1.021 & 3.036 & 4.057 & 20.18 \\
\hline \multirow{5}{*}{$50: 50$} & 5MCC-10kGy & 0.249 & 2.578 & 2.839 & 3.101 & 24.41 \\
& 40MCC-10kGy & 0.353 & 1.531 & 1.675 & 1.911 & 61.43 \\
& 5MCC-50kGy & 0.170 & 1.138 & 2.067 & 2.277 & - \\
& 40MCC-50kGy & 0.379 & 1.413 & 2.996 & 3.349 & 4.65 \\
\hline
\end{tabular}

\section{CONCLUSION}

From this investigation, the irregular irradiation route has offered a promising technique on inducing the compatibility behaviour that enhances the recycled PP composites' properties. The enhancement in stiffness (storage modulus) of composites and the damping property had depended on higher levels of MCC content, rPP:i-rPP ratio and crosslinking value. A greater crosslinking density also slows down the absorption of water into the composites. Sample 50:50/40MCC-10kGy exhibits tremendous properties compared to other compositions.

\section{ACKNOWLEDGEMENT}

The authors would like to thank the International Islamic University Malaysia (IIUM) and Ministry of Higher Education (MOHE), Malaysia (FRGS14-163-0404) for the support of this research.

\section{REFERENCES}

[1] Miranda LF, Pereira NC, Faldini SB, Masson TJ, Silva LGA, Silveira LH. (2009) Effect of ionizing radiation on polypropylene composites reinforced with coconut fibers. In Proceedings of the International Nuclear Atlantic Conference:27 September - 2 October 2009; Rio de Janeiro, Brazil; pp 1-9

[2] Lazim NH, Samat N. (2019) The influence of irradiated recycled polypropylene compatibilizer on the impact fracture behavior of recycled polypropylene/microcrystalline cellulose composites. Polymer Composites, 40(S1): E24-E34.

[3] Lazim NH, Samat N. (2017) Effects of irradiated recycled polypropylene compatibilizer on the mechanical properties of microcrystalline cellulose reinforced recycled polypropylene composites. Procedia Engineering, 184:538-543.

[4] Samat N, Lazim NH, Motsidi SNR, Azlina HN. (2017) Performance properties of irradiated recycled polypropylene as a compatibilizer in recycled polypropylene/microcrystalline cellulose composites. Materials Science Forum, 894:62-65.

[5] Samat N, Motsidi SNR, Lazim NH. (2018) Effects of electron beam radiation dose on the compatibilization behaviour in recycled polypropylene/microcrystalline cellulose composites, IOP Conference Series: Mater. Sci. Eng.,290: 012034.

[6] Moldovan A, Patachia S, Vasile C, Darie R, Manaila E, Tierean M. (2013) Natural fibres/polyolefins composites (I) UV and electron beam irradiation. J. of Biobased Materials and Bioenergy, 7(1):58-79.

[7] Rimdusit S, Wongsongyot S, Jittarom S, Suwanmala P, Tiptipakorn S. (2011) Effects of gamma irradiation with and without compatibilizer on the mechanical properties of polypropylene/wood flour composites. J. of Polymer Research, 18(4):801-809. 
[8] Cleland M, Parks L, Cheng, S. (2003) Applications for radiation processing of materials. Nuclear Instruments and Methods in Physics Research Section B: Beam Interactions with Materials and Atoms, 208:66-73.

[9] Tamada, M. (2018) Radiation processing of polymers and its applications. In Radiation Applications, Volume 7. Edited by Kudo H. Singapore, Springer; pp 63-80.

[10] Cai X, Blanchet P. (2015) Electron-beam curing of acrylate/nanoparticle impregnated wood products. BioResources, 10(3): 3852-3864.

[11] Porto KMB, Napolitano CM, Borrely SI. (2018) Gamma radiation effects in packaging for sterilization of health products and their constituents paper and plastic film. Radiation Physics and Chemistry, 142:23-28.

[12] Kim SW, Park K, Lee SH, Kang JS, Kang KH. (2007) Dependence of mechanical and thermal properties of thermoplastic composites on electron beam irradiation. Int. J. Thermophysics, 28:1067-1073.

[13] Moldovan A, Patachia S, Vasile C, Darie R, Manaila E, Tierean, M. (2013) Natural fibres/polyolefins composites (I) UV and electron beam irradiation. J. of Biobased Materials and Bioenergy, 7(1): 58-79.

[14] Yan J, Kim B, Jeong YG. (2015) Thermomechanical and electrical properties of PDMS/MWCNT composite films crosslinked by electron beam irradiation. J. of Materials Science, 50(16):5599-5608.

[15] Karsli GN, Aytac A, Akbulut M, Deniz V, Güven O. (2013) Effects of irradiated polypropylene compatibilizer on the properties of short carbon fiber reinforced polypropylene composites. Radiation Physics and Chemistry, 84:74-78.

[16] Gomes MG, Ferreira MS, Oliveira RR, Silva VA, Teixeira JG, Moura EA. (2013) Influence of electron beam irradiation on $\mathrm{pp} /$ piassava fiber composite prepared by melt extrusion process. In Proceedings of the International Nuclear Atlantic Conference: 24-29 Novevember 2013; Recife, PE, Brazil;pp 1-10.

[17] Awanis J, Anis Sofia S, Samat N. (2012) Effect of coupling agent on mechanical properties of composite from microcrystalline cellulose and recycled polypropylene. Advanced Materials Research, 576:390-393.

[18] Samat N, Marini CD, Maritho MA, Sabaruddin FA. (2013) Tensile and impact properties of polypropylene/microcrystalline cellulose treated with different coupling agents. Composite Interfaces, 20(7): 497-506.

[19] Zulkifli N, Samat N, Anuar H, Zainuddin N. (2015) Mechanical properties and failure modes of recycled polypropylene/microcrystalline cellulose composites. Materials \& Design, 69:114-123.

[20] Banik I, Bhowmick AK. (2000) Effect of electron beam irradiation on the properties of crosslinked rubbers. Radiation Physics and Chemistry, 58(3):293-298.

[21] Pang Y, Cho D, Han SO, Park WH. (2005) Interfacial shear strength and thermal properties of electron beam-treated henequen fibers reinforced unsaturated polyester composites. Macromolecular Research, 13(5):453-459.

[22] Wongsuban B, Muhammad K, Ghazali Z, Hashim K, Ali Hassan M. (2003) The effect of electron beam irradiation on preparation of sago starch/polyvinyl alcohol foams. Nuclear Instruments and Methods in Physics Research Section B: Beam Interactions with Materials and Atoms, 211(2):244-250.

[23] Essabir H, Achaby ME, Hilali EM, Bouhfid R, Qaissbou A. (2015) Morphological, structural, thermal and tensile properties of high density polyethylene composites reinforced with treated argan nut shell particles. J. of Bionic Engineering, 12:129-141.

[24] Md. Salleh F, Hassan A, Yahya R, Azzahari AD. (2014) Effects of extrusion temperature on the rheological, dynamic mechanical and tensile properties of kenaf fiber/HDPE composites. Composites: Part B, 58; 259-266.

[25] Samat N, Burford R, Whittle A, Hoffman M. (2010) The effects of water and frequency on fatigue crack growth rate in modified and unmodified polyvinyl chloride. Polymer Engineering \& Science, 50(2):352-364.

[26] Samat N, Mokhtar WNA, Zulkifli NI. (2014) Properties of eco-friendly composite from recycled polypropylene. Advances in Environmental Biology, 8(8):2760-2766. 
[27] Pérez-Fonseca AA, Arrelano M, Rodrigue D, González-Núñez R, Robledo-Ortiz J. (2016) Effect of coupling agent content and water absorption on the mechanical properties of coiragava fibers reinforced polyethylene hybrid composites. Polymer Composites, 37(10): 3015-3024. 